In the richest lodes the ores appear to have been concentrated by ascending solutions.

In the third memoir we are transported some 500 miles north-eastward to consider the economic resources of the northern Black Hills of South Dakota. A brief sketch of the general geology of the district is given in part i. (28 pages) by 'T. A. Jaggar, jun., and the rest of the volume, forming part ii., by J. D. Irving and S. F. Emmons, deals fully with the economic resources. The dome-like structure of the Black Hills, with their laccolitic intrusions of igneous rock, is already well known. "They rise like an island in the midst of the Great Plains, with culminating peaks of pre-Cambrian granite intrusive in Algonkian schists, and these same schists and granite may be followed outward from the centre of the Hills to an encircling escarpment of Palæozoic rocks dipping away on the northern, southern, and eastern sides, and mantling over the schists to form an extensive forested limestone plateau on the west." The limestones have been crushed in places into "pseudo-conglomerates," and Dr. Jaggar suggests a similar origin for many supposed conglomerates or "intraformational breccias" that have been described in other parts of the continent.

The picture of the region presented in the first few pages of part i. is remarkably clear and impressive. The Cambrian series of shales, quartzite, sandstone, and
The last memoir of our series, which takes us again 900 miles to the westward, is the description of a geological reconnaissance across the Bitterroot Range and Clearwater Mountains in Montana and Idaho, by Waldemar Lindgren, and is in some respects the most instructive of the series; but unfortunately we have no space in which to do it justice. It deals with a vast tract of mountainous country, for the most part exceedingly difficult to traverse, and as yet very imperfectly explored. A huge " batholith" of granite or quartz-monzonite 300 miles in length from north to south, and 50 to 100 miles in width, occupies the central part of this region, and has been locally pressed and deformed, especially along its eastern margin, into gneiss. Sedimentary rocks are comparatively restricted in their range, and the age of most of those which are exposed is doubtful, as no well defined fossils have been found; but it is believed that, along with complexes of pre-Cambrian age, the Triassic, Carboniferous, and possibly older Palæozoic systems are represented. In the west the country is overspread by the great Columbia River lavas of Tertiary age. The physiographic features of the region are of extreme interest, and are carefully discussed. It is shown that the Clearwater Mountains had already acquired a sharply accentuated topography before the outpouring of the Columbia River basalts, and that the lower portions of the principal valleys were flooded and dammed by the lava-flows. The most important structural feature of the region, however, is the great fault by which the Bitterroot Mountains have been elevated on the west and the Bitterroot valley carried down on the east. This fault-plane is described as being remarkably flat, though apparently normal. It is supposed to represent a twofold movement, by which the foot-wall has been raised and the hanging wall depressed. It indicates a vertical movement of from 4000 to 6000 feet, and the horizontal component is estimated to be at least two miles. The schistose belt of the granite underlies this plane, and the structure is considered to be an outcome of the disturbance. Movement appears to have continued along the fault up to recent times.

G. W. L.

Fig, 2,-.-Upper Valley of Mill Creek, Bitterroot Range, looking East from Main Divide. Notice pronounced $U$-shape of Valley narrowing toward the lower part. The prevailing rock is granite.

thin limestones, $200-400$ feet thick, which rest in bold unconformity upon the upturned edges of the Algonkian schists, include at their base an irregular conylomerate, evidently an ancient beach-deposit. This basal Cambrian conglomerate contains detrital gold, derived from the erosion of auriferous lodes in the Algonkian rocks, and, according to the present authors, has been further enriched by later infiltration. It thus constitutes in favoured localities a gold-producing ore second only in importance to the lodes in the underlying Algonkians. The last-mentioned lodes are usually fissured belts of rock along which the precious metal, accompanied by other minerals, has been more or less irregularly deposited by permeating solutions. Another important source of gold is described under the heading of "Refractory Siliceous Ores." These ores represent the replacement of portions of the Cambrian dolomitised limestones by silica and other minerals, including gold, that appear to have been carried upward in solution by waters ascending along vertical joints. These waters, when checked by a comparatively impervious bed, tended to spread out laterally along the dolomites, which were partially dissolved and replaced by other substances. This part of the memoir is illustrated with some beautiful plates of microscopic slides. Besides gold, the district has yielded ores of silver-lead, wolframite, and a little copper, with some traces of tin. No. 1845 , voI, 71$]$

\section{ANTHROPOLOGICAL NOTES.}

$A \mathrm{~N}$ interesting paper by A. L. Kroeber on the types of Indian culture in California is to be found in vol. ii. of the Publications of the University of California"American Archæology and Ethnology, 1904." Ethnologically, California is characterised by the absence of agriculture and pottery, by the total absence of totemism or gentile organisation, by an unusually simple and loose social organisation in which wealth plays a rather important part, by the very rude development of all arts except basketry, by the lack of realism in art, by a slight development of fetishism and by the conspicuous lack of symbolism and ritualism, by the predominance among ceremonials of mourning and initiation rites, and by a considerable development of true conceptions of creation in mythology. The natives are of an unwarlike nature, and lack intensity and pride. It will therefore be seen that in almost every instance the Californian Indians are among the least characteristic of the Indians of North America, being lacking in the typical qualities of that race, and thus they are the most generalised of the peoples of that continent. In the same volume Dr. Kroeber gives an account of the languages of the coast of California south of San Francisco.

Drs. A. Bloch and P. Vigier have re-examined the hair 
follicles of negroes (Bull. et Mém. Soc. d'Anth., Paris, 1904, p. 124), and have obtained interesting results. The follicle forms at least half a spiral and is not flattened; the distribution of hair on the scalp is uniform, but all the hairs of the same spiral tuft have the intradermic portion of their curves orientated in nearly the same direction, and it is apparently this uniformity of the neighbouring follicles that determines the formation of spiral tufts; a semicircular oblique crest ridge of fibrous tissue constricts the upper portion of the hair bulb, and thus causes the flattening of the hair and its spiral twist.

Mr. E. H. C. Walsh, in an illustrated note on stone implements found in the Darjeeling district (Journ. As. Soc. Bengal, lxxiii. p. 21 ), states that all the implements he found were polished "celts," with the exception of a dumb-bell shaped hammer head. The general belief of the people is that these axe-heads are thunderbolts which have fallen from heaven; they are chiefly found with the medicine men, who use them as charms in their incantations to drive out or cure disease, and also on account of their reputed medicinal properties when mixed with water; on several specimens the scraping or rubbing on stones to obtain medicine is very noticeable. Numerous references to other papers dealing with the subject are given. On p. 27 of the same Journal P. O. Bodding describes some shoulder-headed and other forms of stone implements in the Santal Pargans; it is not yet clear who were the makers of these distinctive implements-possibly they were Mon-Kmer and Munda peoples. The Journal also contains some interesting folklore.

Some time ago M. Verneau directed attention to some skulls from Palæolithic interments at Mentone with a remarkable negroid aspect, and $M$. Hervé has noted two somewhat similar Neolithic skulls from Brittany. Prof. Manouvrier points out in the Bull. et Mém. Soc. d'Anth., Paris (1904, p. II9), that all these "negroid" characters occur in European or other non-African skulls, but they are very rarely found in conjunction. All the skulls of this type are female; in following out this hint Dr. Manouvrier discusses the "negroid" characters, and comes to the conclusion that in a dolichocephalic population in which the prognathism of the men is so marked, a corresponding degree of prognathism in the women, combined with other characters that are characteristic of female skulls, would give a negroid appearance without any need to conclude that there was a negro element in the population. The same author describes $(p, 67)$ a remarkable trepanned Neolithic skull, and (p. Ior) some senile Neolithic skulls.

As the result of a long and careful comparative study of the skeletal variations of the foot in primates and in the races of man, Th. Volkov (Bull. et Mém. Soc. d'Anth. Paris, 1903, 1904) arrives at the following conclusions:The skeleton of the foot of the prosimians bears many traces of the primitive type of foot of the ancient mammals, and presents many intermediate forms between this type and that of the foot of monkeys. The skeleton of the foot of the lower primates appears to be the result of adaptation to arboreal life of ancestors whose foot resembled that of existing rodents. The skeleton of the foot of anthropoids represents the extreme of this adaptation, but at the same time (among the hylobates and partly in the gorilla) the beginning of adaptation to standing and to bipedal progression. The skeleton of the foot in the lower races of man presents as a whole, and for each bone in particular, evident and numerous traces of adaptations characteristic of climbers antecedent to the assumption of the erect attitude and bipedal progression. The ethnical characters range from the oblique and fiat foot to the straight and arched foot. Consequently the arch of the foot represents the most essential character from an anthropological point of view. The index of curvature, that is to say, the relation between the height and length of the foot, or especially the tarso-metatarsian length, should be considered as a very important anthropometric datum. The skeleton of the foot of the new-born infant reproduces primitive and transitory forms in the development of the human foot in general, and thus its study possesses a very great anthropological importance.

\section{UNIVERSITY AND EDUCATIONAL} INTELLIGENCE.

CAMBRIDGE.-The following is the speech delivered by the Public Orator, Dr. Sandys, on Thursday last, in presenting Dr. E. B. Tylor, F.R.S., professor of anthropology in the University of Oxford, for the degree of Doctor in Science honoris causa :-

Adest vir et propter aetatis dignitatem et propter studia in rerum originibus primis exquirendis praeclare posita inter primos merito numerandus, quem iamdudum admirati, nunc demum honore diu debito decoramus. Abhinc annos quinque et quadraginta consuetudines Mexicanas antiquas diligenter exploravit. Deinde de prisco hominum cultu, opere in maximo et doctrinae variae plenissimo, plus quam semel disputavit. Illo vero in opere, animarum praesertim in regno perlustrando aliorum antecursor constitutus, successoribus omnibus facem splendidam praetulit. Denique de anthropologia universa egregie disseruit, hominum ipsorum studium hominibus imprimis proprium esse iure optimo arbitratus. Nemo fortasse magis merito liberalitatem illam Terentianam prae se ferre potest :-

" homo sum, humani nil a me alienum puto."

The proposals forwarded by the Studies Syndicate have been rejected by the Senate by, roughly speaking, three to two. The poll taken was the largest on record, and on the Grace affecting Greek the "non-placets" were 1559 and the "placets" 1052. The result is extremely disappointing to all those who wish to see Cambridge take its rank as a leading university in the Empire. There is, however, a strong consensus of opinion that the matter should not be allowed to rest where it is. Perhaps a consultation between the two opposing bodies might lead to some plan acceptable to the more moderate members of both parties.

The Vice-Chancellor announces that he has appointed Colonel Sir Frank Younghusband, K.C.I.E., to the office of reader on Sir Thomas Rede's foundation for the present year.

Mr. E. H. Hankin, Fellow of St. John's College, and analyst and bacteriologist to the North-West Provinces and Oudh, has been approved by the general board of studies for the degree of Doctor in Science.

Mr. H. O. ARnold-Forster, M.P., Secretary of State for War, has consented to give away the prizes to the students at the Woolwich Polytechnic on April I.

THE Huxley lecture of the University of Birmingham will be delivered by Prof. E. B. Poulton, F.R.S., in the large lecture theatre of the Midland Institute, on Thursday, March 23.

IN the Engineering and Mining Journal, Mr. G. S. Raymer gives an illustrated description of the Simplkins laboratory at Harvard. It is designed for the study of continuous ore-dressing operations on a considerable scale, the plant consisting of a 5-stamp battery and additional apparatus of the most recent type.

THE formal opening of the new building of the École polytechnique of Montreal, in affiliation with Laval University, took place on January 28 . This school was founded in 1874 to give French-Canadian youths an opportunity of obtaining a training in practical science. Its sphere has been limited, but with the new building and improved equipment better results are anticipated.

Mr. Charles H. Hackley, of Muskegon, Mich., has made, we learn from Science, a bequest of 50,000 l. to the Hackley Manual Training School of Muskegon, which, added to $72,000 l$. already given by Mr. Hackley, makes the school's total endowment 122,00ol. Mount Holyoke College will receive, we learn from the same source, $34,400 l$. as the residuary legatee of the late Mr. Edmund $\mathrm{K}$. Turner.

IN an article entitled "The Lesson of Coopers Hill," the Indian Daily Telegraph of February I institutes a comparison between the methods of government in the cases of Coopers Hill and the City and Guilds of London technical colleges. The success of the latter is traced to adaptation in them of the methods followed in the great German polytechnics which is shown by their senates or college boards

NO. I 845 , VOL. 7 I] 